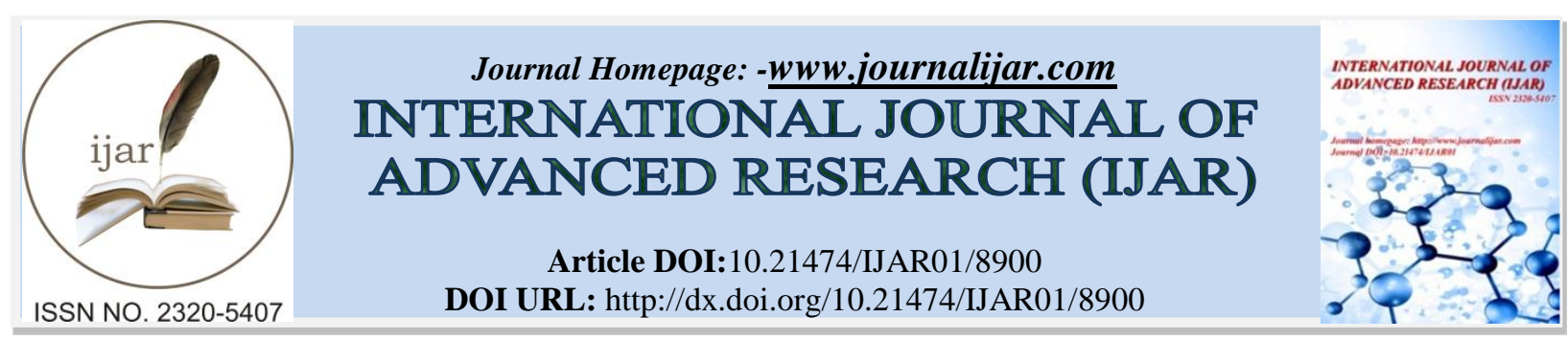

RESEARCH ARTICLE

\title{
IMPACT OF PRIOR WORK EXPERIENCE ON ENTREPRENEURIAL INTENTION AND THEORY OF PLANNED BEHAVIOR IN CONTEXT OF PAKISTAN.
}

\author{
Li Wen Yuan, Sikandar Ali Qalati, Shuja Iqbal, Hamdaoui Hind, and Shaibu Ali. \\ School of Management, Department of Marketing, Jiangsu University, 301 Xuefu Road, Jingkou District, \\ Zhenjiang, Jiangsu, P.R. China.
}

\section{Manuscript Info}

Manuscript History

Received: 12 February 2019

Final Accepted: 14 March 2019

Published: April 2019

Key words:-

Entrepreneurial intention (EI), Prior

Work Experience (PWE),

Entrepreneurial Self Efficacy (ESE),

Perceived Behavioral Control (PBC),

Perceived Family Support (PFS).

\section{Abstract}

The present study aims to investigate the impact of prior work experience influence on the entrepreneurial intention in the context of Pakistan. Where 58\% population lies in the age of 20-30 years, $45 \%$ people hold master degree. $58 \%$ people have experience in private firms. The sample of 438, represents the population of Pakistan. Study used the partial least square structural equation modelling software (PLS-SEM) 3.2.7, and the techniques used involves PLS Algorithm, Bootstrapping, scales used witnessed by using Fornell- Larcker validity and most sensitive techniques heterotrait-monotrait (HTMT) ratio of correlation. The study constructed the four hypothesis in light of recent literature along with the theoretical support. Moreover, study founded the positive relationship between prior work experiences, with entrepreneurial intention. In addition, components of the theory of planned behavior also played a significant role.

Copy Right, IJAR, 2019,. All rights reserved.

\section{Introduction:-}

An economy of developing countries is facing tough time to boost GDP, Pakistan is one of them. Current situation states that the 58\% literacy rate is still stagnant [5] inflation rate increased to 5.9\%. [100] 31.8\% devaluation of rupees [87], the unemployment rate increased to $8.0 \%$ [80]. In addition, small and medium enterprise contribute $40 \%$ to GDP of Pakistan [83]. It's the time to play a role of role model to serve the country. Despite of dependence on government to produce jobs, decrease in taxes and an interest rate, young generation of Pakistan required to indulge in an entrepreneurial activity. The economy can get success by focusing on entrepreneurial activities, it's vital to focus on the determinants which motivate entrepreneurial intensions [97]. EI is concerned with attitudes, subjective norms (support from family, siblings, environment, government etc.), and perceived behavioral control [18].

Most of the countries, their governments, policy makers as well as scholars realized that entrepreneurship plays a vital role in in economic growth and promote the employment, and act as catalyst for the betterment of society [67, 88]. Entrepreneurship is consider a facilitator for the growth of the economy, and give a competitive edge to the developed countries [1, 8]. Furthermore, [76] beliefs that it's the main determinants which fights with societal hindrance and the term unemployment. [31, 64] beliefs that $\mathrm{E}$ is the major element in the economies of developed and developing countries.

Corresponding Author:-Sikandar Ali Qalati.

Address:- School of Management, Department of Marketing, Jiangsu University, 301 Xuefu Road, Jingkou District, Zhenjiang, Jiangsu, P.R. China. 
[13], beliefs that the E creates huge openings for persons to attain freedom and provide assistance to the economy in the form of employment, improvement in productivity, modernization, and economic development. [47] investigated that E positive influence on the economy, not only in the form of salary, jobs, novelty, but it also have added in the growth of per capita income and help out to fight with poverty. [16, 22] stated that $\mathrm{E}$ is one of the motivating factors for youngster and graduates. According to [72] graduates are facing tough time in having jobs, due to limited offerings, and tough criteria's set by companies, which left graduates to have self-employment. Furthermore, [65] investigated that companies hire those applicants who have an entrepreneurial mind set, skills which make them cost effective. Hence, it's vital to understand the determinants which influence individuals to indulge into starting a new venture. According to [53] apart from individual qualities, there are numerous factors which playing role of boosting the E.

[102] states that it's vital to investigate the factors which influence the graduates towards entrepreneurial intentions. [70] stated that prior work experiences affects the decision-making and performance of firms. [77], explored the opulence results between PWE and attitude towards business. [59], stated that individuals having PWE have greater intensions towards business as compared to freshers. [68], also found that PWE has positive effects on EI. In addition, other findings relate to the sector, he investigated that individuals who have worked in private sector have greater influence towards the venture as compared to employees of government. [28, 85], also found the relationship between PWE with EI. As for as particular qualities, a contemporary research proposed that "although researchers have devoted considerable effort to identifying characteristics, traits, values, affective states, and cognitive styles that are associated with entrepreneurial success, there is less research about taking work experience as an independent variable it also support venture creation remain elusive" [77]. [84], also beliefs that having past insights, information about problems, customers, competitors, also enable us have avail better opportunities, as well as influence our EI.

Although there is a lot of research work on personality traits, social support, trainings, competencies, role model in order to know the entrepreneurship intension, but there is less literature on impact of prior work experience on entrepreneurship intension. Is there a relationship between past working experience, and the attitude toward start-up of business, subjective norms and perceived behavioral control? In the context of Pakistan. Present study involved the prior work experience as an independent variable which was slightly used in the literature along with the theory of planned behavior and entrepreneurial intension as the dependent variable. The study was conducted in the context of Pakistan. The study has been conducted by using closed ended questionnaire, convenient method of sampling used, and Partial Least Square techniques has been adapted to measure the scale.

\subsection{Theoretical Background:}

The Theory of Planned Behavior (TPB) by [2], lets us apprehend intensions keeping in view both factors social and personal. TPB states that behavioral achievement depends on both motivation (intention) and ability (behavioral control). According to the theory, there are three independent of intensions. Attitude, Perceived Support (Subjective norms) and Perceived Behavioral control (Self Efficacy) [3].

\section{Attitude:}

Involve the degree to which a person has a positive or negative assessment of the conduct of attention. It requires a deliberate of the results of acting the conduct.

\section{Subjective Norms:}

Involve the acceptance of behavior in the society. It entails either the family, colleague, friends, siblings, and of those important to us support the behavior or not.

\section{PBC:}

Perceived behavioral control is the insight of the comfort or trouble required in acting particular behavior. It diverges keeping the circumstances and movements, which outcomes, insights of interactive mechanism conditional on state. PBC was advanced, \& shaped the swing after the Theory of Reasoned Action to the Theory of Planned Behavior [60].

In the study of entrepreneurship, it's vital to know about the attitude as because it results the insights of acceptability and also stimuli entrepreneurial intentions. While perceived behavioral control has also that much importance it declare the insights the person has of either the ability to control the situations which leads to entrepreneurial 
intension [4]. As per Becker's theory [14], tells that a human capital is the vital factor which support the creation of intellectual abilities, counting attitudes \& acuity of aptitudes. While as per [30] societal capital, perceived support (SN) [63] is consider a vital factor in the formation of human capital.

\subsection{Prior Work Experience (PWE)}

Kolb's Experiential Learning Theory define experiential learning as "the process whereby knowledge is created through the transformation of experience" [58]. Everyone has a story and a past. Some stories are worse than others. According to [49] we can't change the things which happened in the past, but we can alter some of the portion in the future taking past as standards. Hence our prior experience will assist to shape today. There are three types of pre launched experience, most of entrepreneur have behind their successful businesses first they have worked in the same industry, second related industry and third frequent user of the product [46].

Prior work experience can be defined in numerous ways in general, it is any experience a person gain while working in a specific field or occupation. As per disclosure of [78] past work exposure is important for having a bright career. Furthermore, it entails that, no worries work is whether for a short time or longer work exposure always liked by employers and it will aids you in gaining future jobs. Family ties are valuable, but not essential, in establishing transnational ventures [6]. According to [45] people over 40 years, having wider PWE related to entrepreneurial as compared to younger people. In addition [62] stated that PWE positively influence the self-efficacy as well as entrepreneurial expectation. While [41] finds that university students having PWE has the greater level of EI (vs students having no exposure). However, the difference is not statistically significant. According to [12] the engrossment in the creation of diverse businesses also offers chance of having insights of the perils and glitches allied with new firms. Entrepreneurial exposure is key elements connected with contributions and part of entrepreneur in new firm establishment [61]. Precisely, insightful prior knowledges can offers a competitive edge to possessions and meanwhile subsidize to individual conclusion about the likelihood of his/her creating a new venture.

$\mathbf{H}_{1:}$ Prior work experience is positively related to entrepreneurial intention.

\subsection{Entrepreneur Intension (EI)}

There are numerous definition and thoughts about EI. According to [91] EI is a parson readiness to indulge in entrepreneurial action, or to be an entrepreneur. Entrepreneurial conduct is a process that reveals continuously for the world [84]. While as per [29] EI is the tool which enable us to fulfil the aim of firm establishment. EI can also be well-defined as a mindful response and belief by those who wants either to start a new venture or want to become in future [18] define EI as a feeling or mood which entails towards entrepreneurial conduct. [96], beliefs that EI's are fundamental to entrepreneurship development since they are the main reasons for starting new ventures.

Past work exposure of a new venture or being an entrepreneur boost EI, although over inconsequentially [73]. Not that much focus has been put on prior work exposure, which centrals to advanced stages of educational attainment [36]. They notify the bright side of prior work experience, hold that a grip on work can be increased by having a greater level of exposure for that task [34].

\subsection{Conceptual and Hypothesis}

Albeit TPB has been used many of the scholars for different research, but this theory is rarely used to know the effects of the PWE impact of EI, this study emphasis are about discovering the influence of prior work experience. PWE not only block to grab the opportunity, to gain a competitive edge as well as new career with ease, but also surge performance, improve the insights to resolve the problems, an addition to the creation of new venture and also provide support to entrepreneurial behavior [19]. PWE estimated to have a positive influence towards EI [55].

\subsubsection{ATBS and its mediating role}

There are numerous definition of an attitude, [3] beliefs that "it is a disposition to respond favourably or unfavourably to an object, person, institution, or event." In addition [2] hold that distinctive feature of an attitude is its evaluative (pro-con, pleasant-unpleasant) nature. According to [95] findings, there is a greater influence of attitude along with the subjective norms of international student in Turkey. Furthermore, the greater the optimistic attitude towards an act greater level of EI will be to implement that act [7]. [101] found the positive mediation, relationship among PWE and EI. 
According to [56, 75] found that PWE influence attitude towards stating new venture. [38], also found that persons having PWE favor the entrepreneurial life. Furthermore PWE permits persons to analyze the individual significances of initiating a venture [82]. There are numerous factors which influence attitudes towards any behavior [32]. Theory of career choice states that person's views about a job is effect of prior work exposure, also the insights of the attitudes and estimation of perceived support (society, family, friends) toward the job. Such opinions and knowledges, exposure, effect attitudes to a specific occupation and finally the profession best that those persons mark.

According to [81] firms appoint individuals taking PWE as a basis, they use it as one of major parameter, they beliefs that people having prior experience perform better. According to [43] findings ESE along with the personality trait as well as entrepreneurial attitude is the important determinants of EI. In addition [89] indicated that attitude and subjective norms are rated at good level to influence EI, while PBC rated at a very good level to impact EI. Thus:

$\mathbf{H}_{2}$ : Relationship between PWE and EI is mediated by ATBS.

\subsubsection{PFS and its mediating role}

According to [3] TPB states that perceived support of family, friends, society, siblings, offers the personal standards that entrepreneurs may practice to decide. If their EI to initiate to start new venture is recognized and supported by others believed important by them. Conferring to the contemplative assessment procedure, vital persons or group's converse reviews of the person's conduct, such reviews recycled by the individual to comprehend who they are, and how they act. [86] Essential analysis of replicated evaluation spreads this line of cognitive, and advocates that replicated considerations are clarified by the person's personal self-insights. Therefore, persons having PWE, experiences are set out by themselves by using knowledge, skills, and uses the reviews and standard happens to others.

According to [35] PWE affects the perceived family support towards initiating the business. [66], states that societal contacts provide assistance to those having prior work experience related to business. According to [79] findings along with the personality factors subjective norms also have a vital influence on EI of students. [56], found that environment where people work played the role of norms in between PWI and EI.

Furthermore, [4] reviewed methodology advises that only those individuals have greater chances of EI, those have strong beliefs about themselves and perceived support from family, friends etc. [37] recommends that those who don't have family support they become disheartened and eventually not continue to open new venture.

[71], found that knowledge of entrepreneurship, which is part of work experience positively effects the EI by having social norms as a mediator. In universal, greater the perceived support greater will be EI towards new venture/firm/business. Thus,

H3: Relationship between PWE and EI is mediated by PFS.

\subsubsection{PBC and its mediating role}

$\mathrm{PBC}$ is the insight of the comfort or trouble required in acting particular behavior [4]. As per [10] PBC is the insight of means, but this can't be separate from the person's insights of comfort/struggle in the accomplishment of an assignment. People entitled to indulge in those activities which they beliefs they can complete [10]. Self-efficacy consider as the brilliant degree of PBC, meanwhile the notch to which an individual passes self-assurance in their skill to open a venture is straight forwardly associated with their supposed control in implementing that conduct [3]. As it is broad term, it include self-efficacy is grounded on persons' insight of own skills, talents, and capability to accomplish specific jobs, as well as its mirror individual's self-reliance in his/her identifiable aptitude to flourish in such jobs [10]. As per [25] SE is the person's self-assurance in his or her skill to thrive in entrepreneurial activities.

[101] found the positive mediation, relationship among PWE and EI. PWE has positive effects on PBC which leads to starting a new business [82]. [21], found that past experience gives permission to learn skills in order to start a new business. According to [20], ESE effects varieties, ambitions, and struggle, as well as determine when businesspersons look problems. As per [17] findings among six determinants, self-efficacy is an important predicator of EI. In addition [40] beliefs ESE along with the attitude and feasibility have greater impact on EI, while holding that PFS don't have influence on EI. 
In addition [62] used self-efficacy and found that it mediate between the individual's input (PWE) and output (EI). [71], explored the positive mediation, relationship among entrepreneurial knowledge and entrepreneurial intension. More interestingly [99] find that SE is an important factor to know why some persons are motivated and some are not. According to [57] results persons having greater level of SE practice and disclose a greater level of EI. [23], finally it reveals that those who passes greater level of self-confidence they will enjoy greater success in the entrepreneurial activities, process, and intensions. Thus:

$\mathrm{H}_{4}$ : Relationship between PWE and EI is mediated by PBC.

\section{Conceptual framework}

Figure 1:-The figure given above exhibits the conceptual framework of the study, it shows the linkages between variables. The red dotted line shows the direct link between PWE and EI.

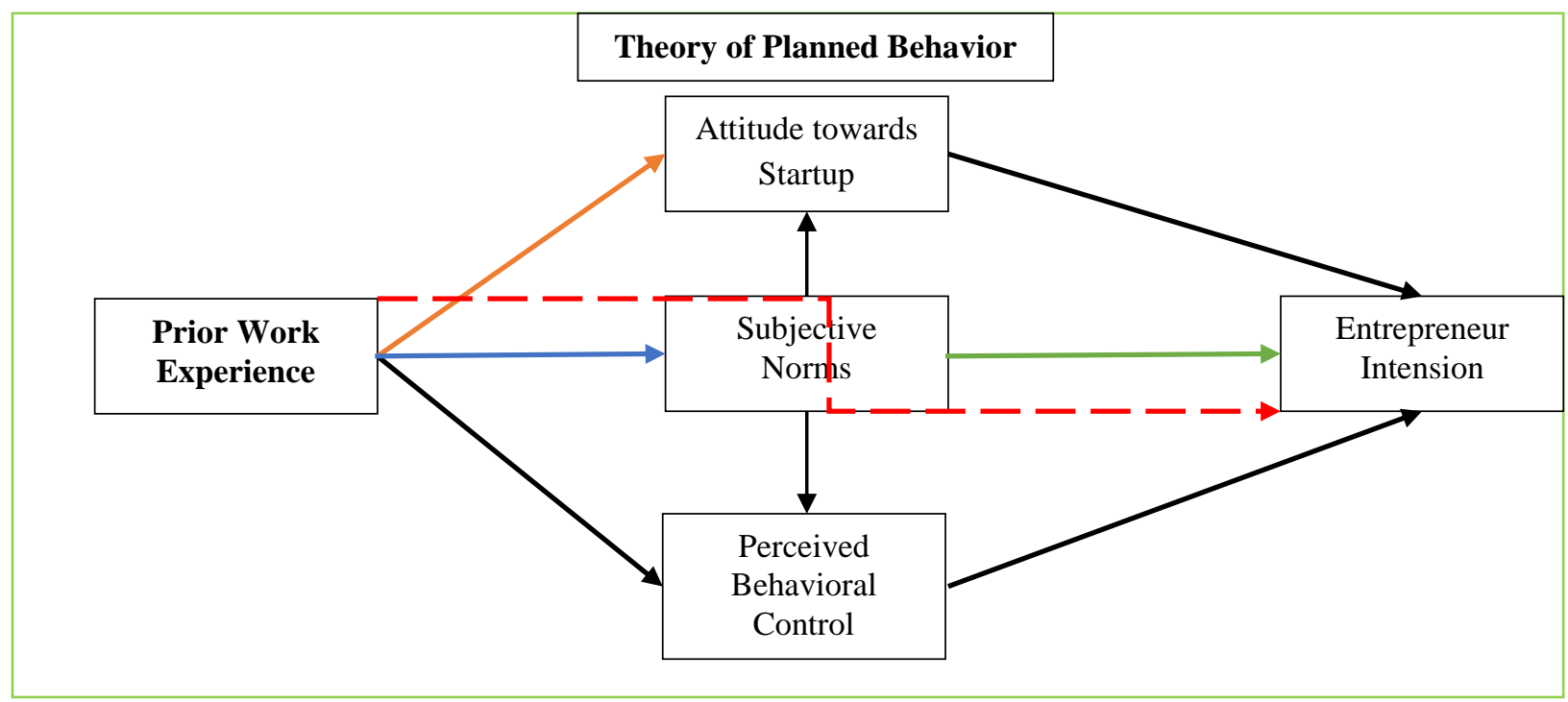

\section{Methods:-}

\subsection{Sample}

The convenience-based method of sampling has been used. In instrument closed ended questionnaire has been used. In Sample overall $438(n=438)$ respondents have filled the questionnaire. A questionnaire has been shared with friends, and universities by using different channels including email, WeChat, and WhatsApp, Facebook. In order to foster a response rate google form has been generated for an ease of respondent. Meanwhile, respondents have all option, either to complete survey online, or fill and sent back via email. This study was conducted in the context of Pakistan.

Table 1:-Demographical Information

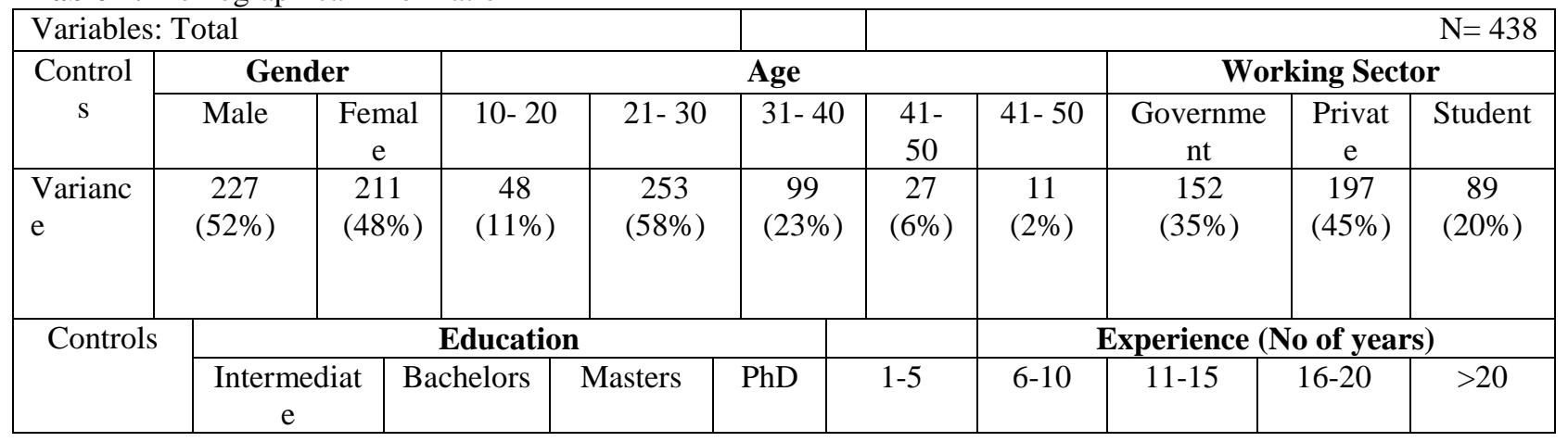




\begin{tabular}{|c|c|c|c|c|c|c|c|c|c|}
\hline Variance & $\begin{array}{c}14 \\
(3 \%)\end{array}$ & $\begin{array}{c}196 \\
(45 \%)\end{array}$ & $\begin{array}{c}198 \\
(45 \%)\end{array}$ & $\begin{array}{c}30 \\
(7 \%)\end{array}$ & $\begin{array}{c}252 \\
(57.5 \%)\end{array}$ & $\begin{array}{c}95 \\
(21.5 \% \\
)\end{array}$ & $21(5 \%)$ & $\begin{array}{c}42 \\
(9.5 \%)\end{array}$ & $\begin{array}{c}28 \\
(6.5 \%)\end{array}$ \\
\hline
\end{tabular}

Note: during conversion into \% round method used.

The table -1: states the demographic information on respondents, out of 438 respondents, $52 \%$ respondents were male, the rest of them female. 58\% respondents lie in the age of 21-30 this figure exhibited the youngsters ratio is higher in the country of Pakistan. $45 \%$ respondents have jobs in the private sector, $20 \%$ students either have worked in the form of internships, part time, or continuing study after having 1 or 2 years of experience. Moreover, $45 \%$ respondents have bachelor levels of education, and $45 \%$ have master level, these figures shows that literacy figure is going to be improved. Furthermore, $57.5 \%$ respondents have 1-5 years' experience, followed by $21.5 \%$ have $6-10$ years.

\subsection{Measures}

\subsubsection{Prior work experience}

We adapted 4 items from the work of [71] to measure the prior work experience. The scale was based on human capital theory [15]. This scale has been used in several studies such as $[11,33]$. The construct validity and reliability of the scales was measured by PLS-3.0 Algorithm techniques. It has a value of Cronbach Alpha 0.932, and composite reliability 0.952 .

\subsubsection{Attitudes towards business start up}

In order to satisfy ATBS 4 point scale was used to measure this variable. The scale was developed by [33] and used by $[93,71]$. The construct validity and reliability of the scale was measured by using PLS-3.0 Algorithm techniques. The scale has a value of Cronbach Alpha 0.82, and composite reliability 0.893 .

\subsubsection{Perceived family support}

We adapted 6 item to assess PFS variable. We adapted 6 items scale from the work of [71]. The scale was developed by [33] used by [92]. The construct validity and reliability of the scale was measured through PLS-3.0 Algorithm techniques. The values Cronbach Alpha 0.896, and composite reliability 0.92.

\subsubsection{Perceived behavioral Control}

In order to measure the PBC 5 item scale has been used, scale items adapted from the work of [71] to measure this variable. The scale was developed by [23, 33, 92]. The construct validity and reliability of the scale was measured having Cronbach Alpha 0.947, and composite reliability 0.959.

\subsubsection{Entrepreneurial intentions}

In total 4 items scale was used to measure this variable. The scale was developed by [33, 93, 92, 71]. The construct validity and reliability of the scale was measured Cronbach Alpha 0.849, and composite reliability 0.899.

\section{Analytical Techniques:}

In this study technique of Bootstrapping, as well as PLS partial least square modelling method has been used. The reasons behind the use of PLS 3.0 and techniques involve. $1^{\text {st }}$ widely received application of modelling [51, 94]. $2^{\text {nd }}$ in order to get detailed information about variables. $3^{\text {rd }}$ Partial least square method is encountered well established method [69]. Hence, keeping in view the importance the partial least square software 3.0 used.

\section{Results:-}

Table 2:-Measurement Model

\begin{tabular}{|l|l|r|r|r|r|}
\hline & Items & \multicolumn{1}{c|}{ Loadings $^{\mathbf{a}}$} & \multicolumn{1}{c|}{$\mathbf{A V E}^{\mathbf{b}}$} & \multicolumn{1}{c|}{$\mathbf{C R}^{\mathbf{c}}$} & \multicolumn{1}{c|}{$\mathbf{C A}^{\mathbf{d}}$} \\
\hline Prior Work & QPWE1 & 0.938 & 0.832 & 0.952 & 0.932 \\
\hline Experience & QPWE2 & 0.945 & & & \\
\hline & QPWE3 & 0.933 & & & \\
\hline & QPWE4 & 0.827 & & & \\
\hline Attitude Towards & QATBS1 & 0.878 & 0.735 & 0.893 & 0.820 \\
\hline Business & QATBS2 & 0.859 & & & \\
\hline
\end{tabular}




\begin{tabular}{|c|c|c|c|c|c|}
\hline Start-up & QATBS3 & 0.834 & & & \\
\hline Perceived family & QPS1 & 0.806 & 0.659 & 0.920 & 0.896 \\
\hline \multirow[t]{5}{*}{ Support } & QPS2 & 0.887 & & & \\
\hline & QPS3 & 0.730 & & & \\
\hline & QPS4 & 0.840 & & & \\
\hline & QPS5 & 0.828 & & & \\
\hline & QPS6 & 0.771 & & & \\
\hline Perceived & QPBC1 & 0.920 & 0.825 & 0.959 & 0.947 \\
\hline Behavioral & QPBC2 & 0.944 & & & \\
\hline \multirow[t]{3}{*}{ Control } & QPBC3 & 0.894 & & & \\
\hline & QPBC4 & 0.909 & & & \\
\hline & QPBC5 & 0.873 & & & \\
\hline Entrepreneurial & QEI1 & 0.873 & 0.691 & 0.899 & 0.849 \\
\hline \multirow[t]{3}{*}{ Intensions } & QEI2 & 0.763 & & & \\
\hline & QEI3 & 0.896 & & & \\
\hline & QEI4 & 0.785 & & & \\
\hline Note: & & & & & \\
\hline
\end{tabular}

1. All item loadings $>0.5$ indicates the indicator reliability $[26,27]$

2. All average variance extracted (AVE) $>0.5$ indicates convergent reliability [9]

3. All composite reliability $(\mathrm{CR})>0.7$ indicates internal consistency [44]

4. All values of $\mathrm{CA}>0.7$ which exhibits the standard set by [74]

The table - 2: depicts that as per the standards set by [74] the Cronbach alpha coefficient must be greater than 0.7 and [52] suggested 04 levels of reliability Level -1 : excellent reliability falls within range of 0.9 and $>$, Level -2 : high reliability in 0.7 to 0.9 , Level -3 : moderate from 0.5 to 0.7 and Level -4 : low but also acceptable $<0.5$. Furthermore, as per [9] the numbers of AVE must be higher than 0.5. Hence the variables used in this study falls in region of excellent reliability and validity.

Table 3:-Discriminant Validity (Fornell-Larcker Criterion)

\begin{tabular}{|c|c|c|c|c|c|}
\hline & ATBS & EI & PBC & PS & PWE \\
\hline Attitude toward business start-up & $* \mathbf{0 . 8 5 7}$ & & & & \\
\hline Entrepreneurial Intentions & 0.559 & $* \mathbf{0 . 8 3 1}$ & & & \\
\hline Perceived family Support & 0.534 & 0.781 & $* \mathbf{0 . 9 0 8}$ & & \\
\hline Perceived behavioral control & 0.71 & 0.652 & 0.648 & $* \mathbf{0 . 8 1 2}$ & \\
\hline Prior work experience & 0.601 & 0.621 & 0.824 & 0.641 & $* \mathbf{0 . 9 1 2}$ \\
\hline
\end{tabular}

* The diagonals are the square root of AVE of the latent variables and indicates highest in column and row.

In the table above value highlighted shows that the square root of AVE which should be greater than 0.5 rule of thumb set by [42] hence in table - 1, this thing has been proven with AVE >0.5. Furthermore, in order to examine the discriminant validity they recommended that AVE should be greater than the correlation among latent variables as depicted in table -2 . The value of AVE is higher in the particular column and row. It's proven that all the measure used in this study has a satisfactory level of discriminant validity.

Table 4:-Heterotrait - Monotrait Ratio (HTMT)

\begin{tabular}{|c|c|c|c|c|c|}
\hline & ATBS & EI & PBC & PFS & PWE \\
\hline Attitude toward business start-up & & & & & \\
\hline Entrepreneurial Intentions & 0.674 & & & & \\
\hline Perceived family Support & 0.837 & 0.743 & & & \\
\hline Perceived behavioral control & 0.602 & 0.863 & 0.685 & & \\
\hline Prior work experience & 0.685 & 0.698 & 0.694 & 0.877 & \\
\hline
\end{tabular}

The table -4 : shows the values of HTMT criterion used to measure multicollinearity according to $[48,90]$ it should not higher than 0.9 . The results shown in the table fulfil criteria, which means that there was no any multicollinearity among the constructs used. 
Table 5:-Latent Variable Correlations

\begin{tabular}{|c|c|c|c|c|c|}
\hline & ATBS & EI & PBC & PFS & PWE \\
\hline Attitude toward business start-up & 1 & 0.559 & 0.534 & 0.71 & 0.601 \\
\hline Entrepreneurial Intentions & 0.559 & 1 & 0.781 & 0.652 & 0.621 \\
\hline Perceived behavioral control & $\mathbf{0 . 5 3 4}$ & 0.781 & 1 & 0.648 & $\mathbf{0 . 8 2 4}$ \\
\hline Perceived family Support & 0.71 & 0.652 & 0.648 & 1 & 0.641 \\
\hline Prior work experience & 0.601 & 0.621 & 0.824 & 0.641 & 1 \\
\hline
\end{tabular}

The table given above states the relationship between variables, 0.559 values show the positive relationship among ATBS and EI. Likewise 0.534 shows a positive relationship between ATBS with PBC. 0.71 positive relationships among ATBS and PFS and 0.601 positive relationships between ATB and PWE. Likewise, all variables have positive relationship among them. The maximum positive relationship $\mathbf{0 . 8 2 4}$ was found between prior work experience and perceived behavioral control. And minimum $\mathbf{0 . 5 3 4}$ was found between attitude towards business start-up and perceived behavioral control.

Table 6:-Hypothesis Analysis

\begin{tabular}{|c|c|c|c|c|c|}
\hline & Beta & SD & t-value & $\begin{array}{c}\mathbf{P} \\
\text { value }\end{array}$ & Decision \\
\hline $\mathbf{H}_{1:}$ Prior work experience -> Entrepreneurial intentions & 0.680 & 0.018 & $\begin{array}{c}* * 37.67 \\
7\end{array}$ & 0.000 & Supported \\
\hline $\begin{array}{c}\text { H }_{2:} \text { Prior work experience -> Attitudes towards business } \\
\text { start-up -> Entrepreneurial intentions }\end{array}$ & 0.063 & 0.023 & $* * 2.715$ & 0.007 & Supported \\
\hline $\begin{array}{c}\mathbf{H}_{3:} \text { Prior work experience -> Perceived behavioral Control } \\
->\text { Entrepreneurial intentions }\end{array}$ & 0.499 & 0.025 & $\begin{array}{r}* * 20.15 \\
9\end{array}$ & 0.000 & Supported \\
\hline $\begin{array}{c}\mathbf{H}_{4:} \text { Prior work experience }->\text { Perceived family support }-> \\
\text { Entrepreneurial intentions }\end{array}$ & 0.119 & 0.03 & $* * 4.000$ & 0.000 & Supported \\
\hline
\end{tabular}

Note: $* *$ p $<0.01($ one-tailed test)

The table - 6: show the hypothesis analysis, along with their coefficient, standard deviation, $\mathrm{t}$-value as well as $\mathrm{p}$ value and their significance.

Initially, $\mathbf{H}_{1}$ : constructed that PWE positively related to EI. The results provided in Table -5 have revealed a significant positive relationship among PWE and EI having positive coefficient $0.680, t=37.677, p$ value 0.000 $<0.01$. Hence results supported the $\mathrm{H}_{1}$. The study supported the work conducted by [41, 61, and 62].

Secondly $\mathbf{H}_{2:}$ developed for the mediating role played by ATBS between PWE and EI. The result also reported a positive relationship with positive coefficient 0.063 , t value 2.175 , and $\mathrm{p}$ value $0.007<0.01$. Thus $\mathrm{H}_{2 \text { : }}$ was also supported the studies conducted by [43, 89, and 94].

Thirdly $\mathbf{H}_{3 \text { : }}$ was constructed that perceived family support mediate between PWE and EI. The results founded with positive coefficient $0.499, \mathrm{t}$ value 20.158 and $\mathrm{p}$ value $0.000<0.01$. Hence $\mathrm{H}_{3}$ : was supported, the studies conducted by [56, 71, and 79].

Finally $\mathbf{H}_{4}$ : was about mediation of PBC among PWE and EI. The positive results and value of beta $0.119, \mathrm{t}$ value 4 , and $\mathrm{p}$ value $0.000<0.01$ also supported the $\mathrm{H}_{4}$ : Hence the hypothesis supported and the work conducted by [17, 40, $71,62]$.

Table 7:-Analysis of $\mathrm{R}^{2}$

\begin{tabular}{|c|r|r|r|r|r|r|r|}
\hline & \multicolumn{1}{l|}{$\begin{array}{l}\text { R } \\
\text { Square }\end{array}$} & $\begin{array}{l}\text { Adjusted } \\
\text { R Square }\end{array}$ & \multicolumn{1}{|l|}{ Beta } & \multicolumn{1}{|l|}{ SD } & t-value & P value & Decision \\
\hline Attitude toward business start-up & 0.362 & 0.36 & 0.362 & 0.04 & 9.062 & 0.000 & Supported \\
\hline Entrepreneurial Intentions & 0.652 & 0.649 & 0.652 & 0.021 & 30.812 & 0.000 & Supported \\
\hline Perceived family Support & 0.679 & 0.678 & 0.679 & 0.026 & 26.525 & 0.000 & Supported \\
\hline
\end{tabular}




\begin{tabular}{|l|l|l|l|l|l|l|l|}
\hline Perceived behavioral control & 0.411 & 0.41 & 0.411 & 0.027 & 15.41 & 0.000 & Supported \\
\hline
\end{tabular}

Note: *In PLS-SEM $\mathrm{R}^{2}$ with values of 0.67 considered substantial, 0.33 considered moderate, and 0.19 as weak [26].

The above table -6 , reveals the assessments of $\mathrm{R}$ which is called the coefficient of determination [26]. It explains the variation in dependent variable which incurs because of one or more independent variable. Or the proportion defined by the independent variables [50]. The value of ATBS $0.362(36.2 \%)$ states that $36.2 \%$ in ATBS were defined by PWE. $0.652(65.2 \%)$ variation in EI is defined by PWE along with other variables. 0.679 (67.9\%) variation in perceived family support defined by the prior work experience. In last $0.411(41.1 \%)$ changes in perceived behavioral control were defined by the prior work experience.

\section{Structural Model}

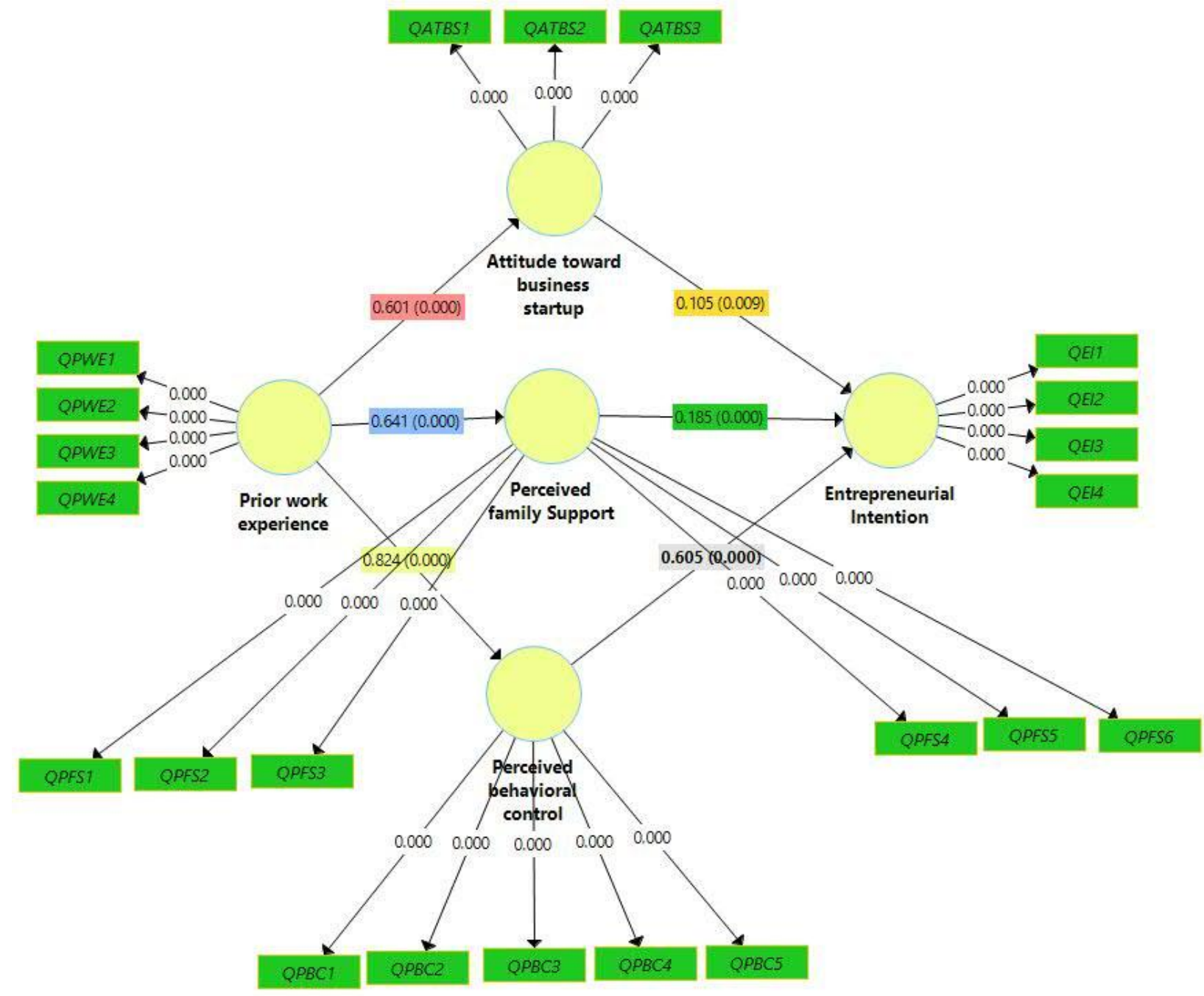

\section{Note: Figure -2}

The bootstrapping technique used for figure - 01, it shows the path coefficients along with their level of significance. All paths have positive coefficients, and were founded significant with $\mathrm{p}$ value $0.000<0.01$.

\section{Discussion:-}

The main aim of study was to investigate the impact of prior work experience on entrepreneurial intension in the light of the theory of planned behavior. The results supported the positive relationship between prior work experience and entrepreneurial intension [17, 43, 41, 53, 62, 98, 6, 13, 24 and 40]. In addition the components of 
TPB attitude towards business startup, perceived family support, and perceived behavioral control also positively acts as mediator between PWE and EI [71, 28, 35, 101, 16, 89, 34 and 39].

This study has numerous applications which can support both theory and practice. Firstly, study conducted in Pakistan, results reveals that 58\% respondent's lies in the age of 21-30 a country having a more youth population can have greater chances of growth in the economy, [54]. Hence it helps government as well as government institutions like small and medium enterprise development authority, perform the task of registration and to develop policies for new firms and allocate resources among them. Secondly, study filled the gap of the weak mediation effect of perceived family support between PWE and EI [39]. Thirdly study provides insights to financial institutions to develop policies for providing loans, to individuals for starting a new venture. Fourthly, it provides insights to institutions to offer entrepreneurship related trainings, as well as workshops. Fifthly study indicates the wide gap between the young generation and government policies, there should be an incubation center in different provinces throughout the Pakistan so that the potential of youth will be utilized. Finally, universities offer entrepreneurship degree courses, so that youth will get wider knowledge, entrepreneurial activities, and startup of business.

\section{1 Limitations and future directions}

This study was conducted in the context of Pakistan. Study can be generalized into other countries and culture. Cross sectional study can be conducted, to investigate the further, directions and influence of individuals having experiences. Study can be conducted in other developing and less developed countries. This study can be explored further with various variable, including family business exposures, entrepreneurial education, quality of experience, chances of conversion of experience into business. Moderating role of gender can be assessed by the study to investigate the ratio of female vs male in to context of Pakistan. Entrepreneurial intension does not mean startup of business, but it exhibits the chances, and wished which may lead to new ventures. There are numerous factors which play role of hindrance, including government regulations, uncertainty of failure, finance, cost of technology and others start a business.

\section{Authors Contribution}

L.W.Y, S.A.Q and S.I are from Jiangsu University. L.W.Y conceptualization and supervision. S.A.Q, S.I, methodology, software, analysis, writing review and editing.

\section{Funding}

This work is not supported by any funding.

\section{Conflicts of Interest}

This study don't have any conflicts of interest

\section{References:-}

1. Acs, Zoltan, J., \& Szerb, L. (2007). Entrepreneurship, Economic Growth and Public Policy. Small Business Economics, 28 (2-3), 109-22.

2. Ajzen 1. (2005). Attitudes, Personality and Behavior. in Attitudes, Personality and Behavior (Pp. 1-191). Open University Press.

3. Ajzen, I. (1991). The Theory of Planned Behavior. Organizational Behavior and Human Decision Process, 50 (2), 179-211.

4. Ajzen, I. (2002). Perceived Behavioral Control, Self-Efficacy, Locus of Control, and the Theory of Planned Behavior. Journal of Applied Social Psychology, 32 (4), 665-683.

5. Alvi, M. (208, April 27). Pakistan's literacy rate stands at 58pc. Retrieved from THE NEWS: https://www.thenews.com.pk/print/309542-pakistan-s-literacy-rate-stands-at-58pc

6. Anuradha, B. (2018, January 4). Prior Startup Experience, Social Networks, and Transitional Entrepreneurship in Silicon Valley. Prior Startup Experience, Social Networks, and Transitional Entrepreneurship in Silicon Valley. Ahmedabad, Ahmedabad, India: Indian Institute of Management Ahmedabad.

7. Armitage, J. C., \& Conner, M. (2001). Efficacy of the Theory of Planned Behavior: A Meta-Analytic Review. British Journal of Social Psychology, 40 (4), 471-499.

8. Audretsch, David, B., Erik, E., Lehmann, \& Susanne, W. (2005). University Spillovers and New Firm Location. Research Policy, 34(7), 1113-22.

9. Bagozzi, R. P., \& Yi, Y. (1988). On the evaluation of structural equation models. Journal of the Academy of Marketing Science, 16(1), 74-94. 
10. Bandura, A. (1989). Regulation of cognitive processes throughperceived self-efficacy. Dev. Psychol, 25 (5), 729-735.

11. Baron, R. A. (2009). Effectual versus predictive logics in entrepreneurial decision making: differences between experts and novices Does experience in starting new ventures change the way entrepreneurs think? Perhaps, but for now, "Caution is essential". Journal of Business Venturing, 24(4), 310-315.

12. Barringer, B. R., Jones, \& F, F. N. (2005). A quantitative content analysis of the characteristics of rapid-growth firms and their founders. Journal of Business Venturing, 20 (5), 663-687.

13. Basu, A., \& Virick, M. (2008). Assessing entrepreneurial intentions amongst students. National Collegiate Inventors \& Innovators Alliance (p. 79). In National Collegiate Inventors and Innovators Alliance.

14. Becker, G. (1964). Human Capital Theory. Human Capital Theory. New York, Columbia, Columbia.

15. Becker, G. S. (1975). Human Capital. Chicago: Chicago University Press.

16. Beeka, B., \& Rimmington, M. (2011). Entrepreneurship as a career option for African youths. Journal of Development entrepreneurship, 16(1), 145-164.

17. Bell, R. (2019). Predicting entrepreneurial intention across the university . Education + Training , 1-18.

18. Bird, B. (1988). Implementing Entrepreneurial Ideas, the case of intension. Academy of Management Review, $13(3), 442-454$.

19. Borman, W. C., Hanson, M. A., Oppler, S. H., Pulakos, E. D., \& White, L. A. (1993). Role of early supervisory experience in supervisor performance. Journal of Applied Psychology, 78 (3), 443-449.

20. Boyd, N., \& Vozikis, G. (1994). The influence of self-efficacy onthe development of entrepreneurs. Entreprenership Theory and Practice, 18 (4), 63-77.

21. Brenner, O., Pringle, C., \& Greenhaus, J. (1991). Perceived fulfillment of organizational employment versus entrepreneurship:Work values and career intentions of business college graduates. Journal of Small Business Management, 29(3), 62-74.

22. Buang, N. (2011). Entrepreneurship career paths of graduate entrepreneurs in Malaysia. Research Journal of Applied Business, 6(4), 282-289.

23. Carr, J. C. (2007). Prior Family Business Exposure as Intergenerational Inflluence and Entrepreneurial Intent A Theory of Planned Behavior Approach. Journal of Business Research, 90, 1090-1098.

24. Chaudhary, R. (2017). Demographic factors, personality and entrepreneurial inclination A study among Indian university students. Education+ Training, 59 (2), 171-187.

25. Chen, C., Greene, P., \& Crick, A. (1998). Does entrepreneurialself-efficacy distinguish entrepreneurs from managers? Journal Business Venturing, 295-316.

26. Chin, W. (1998). The partial least squares approach to structural equation modeling. Modern Methods for Business Research, 295(2), 295-336.

27. Chin, W. (2010). How to write up and report PLS analyses inVinzi,V.E.,Chin,W.W.,Henseler,J and Wang, H (Eds). Berlin Heidelberg,: Springer,.

28. Chlosta, S., Patzelt, H., Klein, S., \& Dormann, C. (2012). Parental role models and the decision to become selfemployed: The moderating effect of personality. Small Business Economics, 38(1), 121-138.

29. Choo, S, \& Wong, M. (2006). Entrepreneurial intention: Triggers and barriers to new venture creations in Singapore. Singapore Management Review, 28 (2), 47.

30. Coleman, J. S. (1988). Social Capital in the Creation of Human Capital. American Journal of Sociology 94, 95120.

31. Díaz-García, C., González-Moreno, Á., \& Sáez-Martínez, F. J. (2015). Ecoinnovation: Insights from a literature review Innovation. Management, Policy and Practice, 14(1), 6-23.

32. Dick, T. P., \& Rallis, S. F. (1991, July). Factors and Influences on High School Student's Career Choices. Journal for Research in Mathematics Education, 22, 281-2 92.

33. Dimov, D. (2010). Nascent entrepreneurs and venture emergence: opportunity confidence, human capital, and early planning. Journal of Management Studies, 47(6), 1123-1153.

34. Dokko, G., Wilk, L., \& Rothbard, P. (2009, January-February). Unpacking Prior Experience How Career History Affects Job Performance. Organization Science, 20(1), 51-68.

35. Douglas, E., \& Shepherd, D. (2000). Entrepreneurship as a utility maximizing response. Journal of Business Venturing, 15(3), 231-251.

36. Dreher, F. G., \& Ryan, C. K. (2000, August). Prior Work Experience and Academic Achievement Among FirstYear MBA Students. Research in Higher Education, 41(4), 505-525.

37. Dyer J, H. (1992). The Entrepreneurial Experience: Confronting Career Dilemmas of the Start-Up Executive. San Francisco: Jossey-Bass. 
38. Dyer, G. (1994). Towards a Theory of Entrepreneurial Careers, Entrepreneurship. Theory \& Practice, 19 (2), 721.

39. Entrialgo, M., \& lglesias, V. (2017). Are the intension to entreprenurship of Men and Women Shaped Differently? The Impact of Entreprenurial Role Model Exposure and Entreprenusrhip Education. Entreprenurship Research Journal, 1-14.

40. Esfandiara, K., Tehranib, M., Prattc, S., \& Altinayd, L. (2017). Understanding entrepreneurial intentions: A developed integrated structural model approach. Journal of Business Research, 94(2019), 172-182.

41. Fatoki, O. (2014, May). The Entrepreneurial Intention of Undergraduate Students in South Africa The Influences of Entrepreneurship Education and Previous Work Experience. Mediterranean Journal of Social Sciences, 5(7), 294-299.

42. Fornell, C., \& Larcker, F. D. (1981). Evaluating Structural Equation Models with Unobservable Variables and Measurement Error. Journal of Marketing Research, 39-50.

43. Fragoso, R., Junior, W., \& António Xavier, A. (2019). Determinant factors of entrepreneurial intention among university students in Brazil and Portugal. Journal of Small Business \& Entrepreneurship, 1-25.

44. Gefen, D., Straub, D., \& Boudreau, M.-C. (2000). Structural Equation Modeling and Regression Guidelines for Research Practice. Communications of the Association for Information Systems, 4(7), 1-77.

45. Gielnik, M., Zacher, H., \& and Wang, M. (2018). Age in the entrepreneurial process The role of future time perspective and prior entrepreneurial experience. Journal of Applied Psychology, 103 (10), 1067-1085.

46. Glauser, M. (2016, May 5). Entrepreneur Europe. Retrieved from https://www.entrepreneur.com: https://www.entrepreneur.com/article/275091

47. Goetz, S., Fleming, D., \& Rupasingha, A. (2012). The Economic impacts of self-employment. Journal of Agricultural and Applied Economics, 44(3), 315-321.

48. Gold, A., Malhotra, A., \& Segars, A. (2001). Knowledge Management: An Organizational Capabilities Perspective. Journal of Management Information Systems, 18(1), 185-214.

49. Gomes, K. (2013, June Sunday). Past experiences help change the future. Past experiences help change the future. Srilanka: sundayobserver.

50. Hair, J., Black, W., Babin, B., \& Anderson, R. (2010). Multivariate Data Analysis, 7th ed. Prentice Hall,Upper Saddle River,NJ.: Prentice Hall,Upper Saddle River,NJ.

51. Hair, J., Sarstedt, M., \& Ringle, C. M. (2012). An assessment of the use of partial least squares structural equation modeling in marketing research. Journal of the Academy of Marketing Science, 40(3), 414-433.

52. Hinton, P. R., Brownlow, C., McMurray, I., \& Cozens, B. (2004). SPSS Explained. : . East Sussex, England: Routledge Inc.

53. Ismail, M., Khalid, S., Othman, M., Jusoff, K., Abdul Rahman, N., Mohammed, K., \& Shekh, R. (2009). Entrepreneurial intention among Malaysian undergraduates. International Journal of Business and Management, 4(10), 54-60.

54. Ji, R. (2018, March 19). Why Young People Have an Advantage in Entreprenurship. Retrieved from Influencive: https://www.influencive.com/young-people-advantage-entreprenurship/

55. Kautonen, T; Luoto, S; Tornikoski, E.T. (2011). Influence of work history on entrepreneurial intentions in prime age and third age a preliminary study. International Small Business Journal, 28(6), 583-601.

56. Kautonen, Teemu, Luoto, Seppo, \& Tornikoski, E. (2010). Influence of work history on entrepreneurial intentions in 'prime age' and 'third age': A preliminary study. International Small Business Journal, 28(6), 583601 .

57. Kickul, J., Wilson, F., Marlino, D., \& Barbosa, S. (2008). Are mis-alignments of perceptions and self-efficacy causing gender gapsin entrepreneurial intention among our nation's teens? Journal of Small Business and Enterprise Development, 15 (2), 321-335.

58. Kolb, D. A. (1984). Experiantial learning Experience as the Source of Learning and Development. Experience as the Source of Learning and Development. Englewood Cliffs NJ Prentice.

59. Kolvereid, L. (1996). Prediction of employment status choice intention. Entrepreneurship Theory and Practice, $21(1), 47-57$.

60. LaMorte, \& Wayne, W. (2018, August 29). sphweb. Retrieved from http://sphweb.bumc.bu.edu: http://sphweb.bumc.bu.edu/otlt/MPH-

Modules/SB/BehavioralChangeTheories/BehavioralChangeTheories3.html

61. Lee, D., \& Tsang, E. (2001). The effects of entrepreneurial personality, background and network activities on venture growth. Journal of Management Studies, 38 (4), 583-602.

62. Liguori, E., Bendickson, J., \& McDowell, W. (2017). Revisiting entrepreneurial intentions: a social cognitive career theory approach. Int Entrep Manag J , 4-12. 
63. Liñán, F., \& Chen, Y. (2009). Development and cross-cultural application of a specific instrument to measure entrepreneurial intentions. Entrepreneurship Theory and Practice,, 593-618.

64. Lindh, I., \& Thorgren, S. (2016). Entrepreneurship education: the role of local business. Entrepreneurship and Regional Development, 28(5-6), 313-336.

65. Lourenço, F., Taylor, T., \& Taylor, D. (2013). Integrating education for entrepreneurship in multiple faculties in "half-the-time" to enhance graduate entrepreneurship. Journal of Small Business \& Enterprise Development, 20(3), $503-525$.

66. MacMillan, I. (1986). To really learn about entrepreneurship, let's study habitual entrepreneurs. Journal of Business Venturing, 1(3), 241-243.

67. Mari, M., Poggesi, S., \& De Vita, L. (2016). Family embeddedness and business performance: evidences from women-owned firms. Management Decision, 54(2), 476-500.

68. Mazzarol, T. V. (1999). Factors influencing small business start-ups. International Journal of Entrepreneurial Behavior and Research, 5 (2), 48-63.

69. McDonald, R. (1996). Path analysis with composite variables. Multivariate Behavioral Research, 31(2), 239270.

70. McStay, D. (2008). An investigation of undergraduate student self-employment intention and the impact of entrepreneurship education and previous entrepreneurial experience.

71. Miralles, F., Giones, F., \& Riverola, C. (2015). Evaluating the impact of prior experience in entrepreneurial intention. Int Entrep Manag J , 1-23.

72. Mwasalwiba, E. (2010). Entrepreneurship education: a review of its objectives, teaching methods, and impact indicators. Education + Training, 52(1), $20-47$.

73. Nguyen, C. (2018, April). Demographic factors, family background and prior self-employment on entrepreneurial intention - Vietnamese business students are different: why? Journal of Global Entreprenurship Research, 8(10), 1-17.

74. Nunnally, J. C. (1978). Psychometric Theory.: New York: McGraw-Hill.

75. Parker, S. (2004). The economics of self-employment and entrepreneurship. Cambridge: Cambridge University Press.

76. Parker, S. C. (2018). The Economics of Entrepreneurship. Cambridge: Cambridge University Press.

77. Peterman NE and Kennedy, J. (2003). Enterprise education Influencing students' perceptions of entrepreneurship. Entrepreneurship Theory and Practice, 28 (2), 129-144.

78. Prospects.ac.uk. (2019). Jobs and Work Experience . Retrieved from Prospectus: https://www.prospects.ac.uk/jobs-and-work-experience/work-experience-and-internships

79. Purba, R. (2019). Entrepreneurial Intention of Sari Mutiara Indonesia University Student In Medan. Journal of Accounting Auditing and Business, 2(1), 1-7.

80. Rana, S. (2018, October 1). Core inflation jumps to four-year high at $8 \%$. Retrieved from The Express Tribune: https://tribune.com.pk/story/1815905/2-pakistans-inflation-slows-5-12/

81. Rynes, S. L., Orlitzky, M. O., \& Bretz, R. D. (1997). Experienced hiring versus college recruiting: Practices and emerging trends. Personnel Psychology, 50 (2), 309-339.

82. Scherer, R., Adams, J., \& Wiebe, F. (1989). Developingentrepreneurial behaviors: A social learning theory perspective. Journal of Organizational Change Management, 2(3), 16-27.

83. Seth, N., Tahir, S., Zafar, F., \& Anas, M. (2017). Opportunities for SMEs under China Pakistan Economic Corridor (CPEC) An Exploratory Study. SME Observer, 7, 1-24.

84. Shane, S. (2000). Prior knowledge and the discovery of entrepreneurial opportunities. Organization Science, 11 (4), 448-469.

85. Shook, C., Priem, Richard, L., \& McGee, J. (2003). Venture creation and the enterprising individual: A review and synthesis. Journal of Management, 29(3), 379-399.

86. Shrauger, J., Sidney, \& Schoeneman, T. J. (1979, May ). Symbolic interactionist view of self-concept: Through the looking glass darkly. Psychological Bulletin, 86 (3), 549-573.

87. Siddiqui, S. (2018, November 30). Monetary policy: SBP hikes key interest rate by 150 basis points to $10 \%$. Retrieved from The Exprees Tribune: https://tribune.com.pk/story/1857528/2-monetary-policy-sbp-hikes-keyinterest-rate-150-basis-points-10/

88. Song, L., \& Winkler, C. (2014). China's trans-regional entrepreneurship. Journal of Entrepreneurship in Emerging Economies, 6(3), 202-222.

89. Soon, N., Ahmad, A., \& Ibrahim, N. (2019). Understanding the Motivation that Shapes Entrepreneurship Career Intention. Entrepreneurship - Development Tendencies and Empirical Approach, 291-308. 
90. Teo, T., Srivastava, S., \& Jiang, L. (2008). Trust and electronic government success an empirical study. Journal of Management Information Systems, 25(3), 99-132.

91. Tkachev, A., \& Kolvereid, L. (1999). Self-employment intentions among Russian students. Entrepreneurship \& Regional Development, 11 (3), 269-280.

92. Tsai, K.H, Chang, H.C, \& Peng, C. (2014). Extending the link between entrepreneurial self-efficacy and intention: a moderated mediation model. Int Entrep Manag J .

93. Tuan, N., Ha, D., Thao, V., Anh, D., \& Long, N. (2019). Factors affecting entrepreneurial intentions among youths in Vietnam. Children and Youth Services Review.

94. Umrani, W., Kura, K., \& Ahmed, U. (2018). Corporate entrepreneurship and business performance The moderating role of organizational culture in selected banks in Pakistan. PSU Research Review, 2(1), 59-80.

95. Usman, B., \& Yennita. (2019). Understanding the entrepreneurial intention among international students in Turkey. Journal of Global Entrepreneurship Research, 9(10), 1-21.

96. Van Gelderen, M. B. (2008). Explaining entrepreneurial intentions by means of the theory of planned behavior. Career Development International, 13 (6), 538-559.

97. Vinogradov, E., Kolvereid, L., \& Timoshenko, K. (2013). Predicting entrepreneurial intentions when satisfactory employment opportunities are scarce. Education+Training, 719-737.

98. W, W., Lu, W., \& Millington, J. (2011). Determinants of Entrepreneurial Intention among College Students in China and USA. Journal of Global entrepreneurship research, 1(1), 35-44.

99. Wilson, F., Kickul, J., \& Marlino, D. (2007). Gender, entrepreneurial self-efficacy, and entrepreneurial career intentions Implications for entrepreneurship education. Entrepreneurship: Theory and Practice, 31 (3), 387-406.

100.Zaidi, H. (2018, June 25). With economic expansion, Pakistan facing jobless growth. Retrieved from The Express Tribune: https://tribune.com.pk/story/1741689/2-economic-expansion-pakistan-facing-jobless-growth/

101.Zapkau, F., Schwens, C., Steinmetz, H., \& Kbst, R. (2014). Disentangling the effect of prior entreprenurial exposure on entreprenurial intension. Journal of Business Research, 1-15.

102.Zellweger, T., Sieger, P., \& Halter, F. (2011). Should I stay or should I go? Career choice intentions of students with family business background. Journal of Business Venturing, 26(5), 521-536. 